J. Clin. Chem. Clin. Biochem.

Vol. 26, 1988, pp. $573-578$

(C) 1988 Walter de Gruyter \& Co. Berlin - New York

\title{
Differential Turbidimetric Assay for Subpopulations of Lipoproteins Containing Apolipoprotein A-I
}

\author{
By W. März, M. Trommlitz and W. Groß \\ Gustav Embden-Zentrum der biologischen Chemie der Johann Wolfgang Goethe-Universität, Frankfurt/Main, \\ FRG
}

(Received February 12/July 12, 1988)

Summary: A differential immunoturbidimetric procedure for the quantitation of apolipoprotein A-I associated with lipoproteins LpA (containing both apolipoprotein A-I and apolipoprotein A-II) and with lipoproteins LpA-I (containing apolipoprotein A-I but no apolipoprotein A-II) is presented. Lipoproteins containing apolipoprotein A-II are precipitated with an anti-apolipoprotein A-II antibody. The resulting immunoprecipitate is sedimented and $L \mathrm{pA}-\mathrm{I}_{\mathrm{A}-\mathrm{I}}$ is measured in the supernate. Whereas $\mathrm{LpA}-\mathrm{I}_{\mathrm{A}-\mathrm{I}}$ concentrations differed significantly between normolipidaemic men and women $(0.75$ and $1.00 \mathrm{~g} / \mathrm{l}$, respectively), there was virtually no sex related difference in $\mathrm{LpA}_{\mathrm{A}-\mathrm{I}}\left(0.83\right.$ and $0.88 \mathrm{~g} / \mathrm{l}$, respectively). $\mathrm{LpA}-\mathrm{I}_{\mathrm{A}-\mathrm{I}}$ was predominantly correlated with $\mathrm{HDL}_{2}$-cholesterol $\left(r_{\mathrm{s}}=0.630\right)$, whereas $\mathrm{LpA}_{\mathrm{A}-\mathrm{I}}$ was statistically associated with $\mathrm{HDL}_{3}\left(\mathrm{r}_{\mathrm{s}}=0.417\right)$.

\section{Introduction}

Plasma $\mathrm{HDL}^{1}$ ) are involved in cholesterol esterification and transport. Clinical and epidemiological data suggest an inverse relationship between HDL concentration and cardiovascular risk (1). HDL do not consist of an homogeneous molecular species, but represent a complex mixture of lipoprotein particles differing in physicochemical characteristics such as hydrated density, particle size, lipid and apolipoprotein composition (2).

Apolipoprotein A-I and apolipoprotein A-II are the major HDL apolipoproteins. Together they constitute approximately $90 \%$ of the protein associated with HDL. In normolipidaemic human plasma more than

\footnotetext{
1) Abbreviations: VLDL, LDL, HDL: very low, low, and high density lipoproteins; LpA, lipoproteins with apolipoprotein A-I and apolipoprotein A-II; LpA-I, lipoproteins with apolipoprotein $\mathrm{A}-\mathrm{I}$ but no apolipoprotein $\mathrm{A}-\mathrm{II}$; $\mathrm{LpA}_{\mathrm{A}-\mathrm{I}}$ $\mathrm{LpA}-\mathrm{I}_{\mathrm{A}-\mathrm{I}}$, apolipoprotein A-I associated with LpA and LpAI, respectively; EDTA, ethylenediaminetetraacetate; TRIS, tris(hydroxymethyl)aminomethane; ELISA, enzyme-linked immunosorbent assay.
}

$90 \%$ of apolipoprotein A-I and $95 \%$ of apolipoprotein A-II are found within the HDL density range. Both apolipoproteins modulate lecithin cholesterol acyltransferase (EC 2.3.1.43) activity (3) and appear to be ligands for HDL receptors (4). Apolipoprotein A-II is an activator of hepatic triacylglycerol lipase (EC 3.1.1.34) (5).

At least two forms of apolipoprotein A containing lipoproteins can be distinguished: particles with both apolipoprotein A-I and apolipoprotein A-II (= LpA), and particles with apolipoprotein A-I but no apolipoprotein A-II (= LpA-I) (6-9). Recent observations suggest that LpA-I, but not LpA, promote cholesterol efflux from cultured adipose cells (10).

Differential quantitation of the two particle species has beèn accomplished by 'tandem gel' electroimmunoassay $(11,12)$, differential antibody ELISA (13) and radioimmunoassay following immunoprecipitation (14). Herein we report the development of a simple immunoturbidimetric procedure for the quantification of the two particle species in terms of their apolipoprotein A-I moiety $\left(\mathrm{LpA}_{\mathrm{A}-\mathrm{I}}\right.$ and $\left.\mathrm{LpA}-\mathrm{I}_{\mathrm{A}-\mathrm{I}}\right)$. 


\section{Materials and Methods}

Plasma samples

Blood samples were obtained from healthy donors after an overnight fast and drawn into tubes containing EDTA $\cdot \mathrm{K}_{2}$ (final concentration $1.5-2 \mathrm{~g} / \mathrm{l}$ ). Plasma was recovered by low speed centrifugation $(1500 \mathrm{~g}, 30 \mathrm{~min})$.

\section{Preparation of LpA-I}

HDL were isolated from pooled human serum (supplemented with $0.4 \mathrm{~g} / 1$ EDTA $\cdot \mathrm{Na}_{2}$ and $0.5 \mathrm{~g} / 1 \mathrm{NaN}_{3}$ ) by sequential preparative ultracentrifugation in a KONTRON type TFT 50.38 rotor within the density range of $1.063 \mathrm{~kg} / 1\left(44000 \mathrm{~min}^{-1}\right.$, $\left.2.6 \cdot 10^{8} \mathrm{~g} \cdot \mathrm{min}\right)$ and $1.21 \mathrm{~kg} / \mathrm{l}\left(44000 \mathrm{~min}^{-1}, 3.4 \cdot 10^{8} \mathrm{~g} \cdot \mathrm{min}\right)$. Densities were adjusted with solid $\mathrm{NaBr}$ and monitored with a DMA 55 digital precision density meter (A. Paar, Graz, Austria). HDL were washed by recentrifugation at $\mathrm{d}=1.21 \mathrm{~kg} / \mathrm{l}$ and then subfractionated by chromatofocusing as described by Nestruck et al. (15). In brief, HDL (25-35 mg protein) were dialysed against the chromatofocusing starting buffer (piperazine- $\mathrm{HCl}, \mathrm{pH} 5.8$ ), applied to a column (bed height $38 \mathrm{~cm}$, diameter $1 \mathrm{~cm}$ ) with Polybuffer Exchanger (Pharmacia Fine Chemicals, Uppsala, Sweden) and eluted with Polybuffer 74 (diluted 1:15 with bidistilled water, $\mathrm{pH} \mathrm{4.0)}$ ) at a flow rate of $22 \mathrm{ml} / \mathrm{h}$. Additional chromatofocusing experiments were carried out with $250 \mathrm{ml} / \mathrm{l}$ glycerol present in all solutions.

\section{'Tandem gel' electroimmunoassay for $\mathrm{LpA}_{\mathrm{P}} \mathrm{I}_{\mathrm{A}-\mathrm{I}}$}

An electroimmunoassay plate was subdivided into anti-apolipoprotein A-II and anti-apolipoprotein A-I containing sections. During sample migration, lipoproteins containing apolipoprotein A-II were retained in the anti-apolipoprotein A-II containing section, whereas LpA-I reached the attached gel with antiapolipoprotein A-I $(11,12)$.

Our electrophoresis buffer contained $25 \mathrm{mmol} / \mathrm{l}$ barbital, 70 $\mathrm{mmol} / \mathrm{l}$ TRIS- $\mathrm{HCl}, \mathrm{pH} 8.8,107 \mathrm{mg}$ calcium lactate, and 130 $\mathrm{mg} / \mathrm{l} \mathrm{NaN}$. The gel consisted of $10 \mathrm{~g} / \mathrm{l}$ agarose (Seakem LE, $-\mathrm{mr}=0.10-0.15$ ), and $20 \mathrm{~g} / \mathrm{l}$ dextran T70 (Pharmacia). Rabbit anti-apolipoprotein A-II (35 ml/l) (Immuno AG, Vienna, Austria) or rabbit anti-apolipoprotein A-I ( $40 \mathrm{ml} / \mathrm{l})$ (Immuno) were added to the gel solution. The sample volume was $5 \mu \mathrm{l}$. Electrophoresis was performed at a constant current of $20 \mathrm{~mA}$ and $15^{\circ} \mathrm{C}$ for $5 \mathrm{~h}$. Staining with Coomassie Brilliant Blue was performed as described (16), and rocket lengths were determined in tenths of a millimeter with a viewer for immunoanalysis (Behringwerke, Marburg, FRG).

\section{Non-competitive ELISA for apolipoprotein A-II}

Microtitre plates (Nunc Immuno Plate I) were coated overnight with $0.1 \mathrm{ml}$ anti-apolipoprotein A-II- $\gamma$-globulin (from sheep, Boehringer Mannheim) diluted 1:500 (corresponding to a final concentration of around $7 \mathrm{mg} / \mathrm{l}$ specific anti-apolipoprotein A-II) in $0.2 \mathrm{~mol} / 1$ carbonate buffer, $\mathrm{pH} 10.0$, blocked in $10 \mathrm{~g} / \mathrm{l}$ gelatine (in coating buffer), and washed with $0.2 \mathrm{ml}$ phosphate buffered saline containing $0.5 \mathrm{ml} / 1$ Tween 20 . Samples $(0.1 \mathrm{ml})$ were incubated for $4 \mathrm{~h}$ and the solid phase was subsequently blocked, washed twice, and incubated $1 \mathrm{~h}$ with $0.1 \mathrm{ml} 1: 500$ diluted anti-apolipoprotein A-II (from rabbit, Immuno). After three additional washes the wells were incubated for $1 \mathrm{~h}$ with

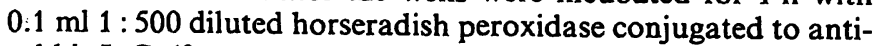
rabbit-IgG (from goat, Biorad Laboratories, Munich, FRG). Colour was developed with an $o$-phenylene diamine (OPD) reagent (Abott Diagnostic Products, Wiesbaden, FRG). The reaction was stopped by addition of $0.5 \mathrm{~mol} / 1 \mathrm{H}_{2} \mathrm{SO}_{4}$ and absorbances were read at $450 \mathrm{~nm}$ (Titertek MCC 340, Flow Laboratories).
Differential turbidimetric measurement of $\mathrm{LPA}_{\mathrm{A}-\mathrm{I}}$ and $\mathrm{LpA}-\mathrm{I}_{\mathrm{A}-\mathrm{I}}$

Lipoproteins containing apolipoprotein A-II were immunoprecipitated with an antibody specific for apolipoprotein A-II. Subsequently, immune complexes were sedimented by centrifugation and LpA-I $\mathrm{I}_{\mathrm{A}-\mathrm{I}}$ was determine, in an aliquot of the supernate.

In detail: Plasma was diluted 20 -fold with $10 \mathrm{mmol} / 1$ potassium phosphate, $\mathrm{pH} 7.4,0.15 \mathrm{~mol} / \mathrm{l} \mathrm{NaCl}$. Sheep polyclonal antiapolipoprotein A-II ( $\gamma$-globulin fraction, $3.5 \mathrm{~g}$ specific antibody per litre, Boehringer Mannheim) was diluted tenfold with the same buffer additionally containing $40 \mathrm{~g} / \mathrm{l}$ polyethylene glycol $\left(M_{\mathrm{r}} 6000\right.$, Serva Heidelberg, FRG). In addition, 10-, 15-, 20-, 30 -, and 40-fold dilutions of the secondary standard serum, sample blanks $(1.0 \mathrm{ml}$ phosphate $/ \mathrm{NaCl}$ with polyethylene glycol plus $50 \mu \mathrm{l}$ of the diluted sample) and a reagent blank were prepared. Diluted sample or standard $(50 \mu \mathrm{l})$ was mixed with $1 \mathrm{ml}$ of the diluted antibodies. After incubation for $21 / 2 \mathrm{~h}$ at $20-25^{\circ} \mathrm{C}$, the mixture was swirled and absorbances read at $365 \mathrm{~nm}$ : sample against reagent blank and sample blank against phosphate buffer with polyethylene glycol. This step provided a value for the total apolipoprotein A-II concentration. The immunoprecipitate was then sedimented by centrifugation at $2000 \mathrm{~g}$ for $20 \mathrm{~min}$, and $0.9 \mathrm{ml}$ of the supernate was transferred to fresh tubes (It has been confirmed by absorbance measurements of the supernate that the immunoprecipitate is completely removed under these conditions). $0.1 \mathrm{ml}$ undiluted polyclonal anti-apolipoprotein A-I ( $\gamma$-globulin fraction from sheep, $5.2 \mathrm{~g}$ specific antibody per litre, Boehringer Mannheim) was added, incubated for $2 \frac{1}{2} \mathrm{~h}$, and the absorbance measurements were repeated. Finally, LpA-I $\mathrm{I}_{\mathrm{A}-\mathrm{I}}$ was determined by reference to the calibration curve, and $\mathrm{LpA}_{\mathrm{A}-\mathrm{I}}$ was calculated as the difference between total apolipoprotein A-I (measured with the sheep antiapolipoprotein A-I from Boehringer Mannheim according to the supplier's instructions) and LpA-I $\mathrm{I}_{\mathrm{A}-\mathrm{I}}$.

\section{Standardization}

Two approaches were pursued to quantify $\mathrm{LpA}_{\mathrm{A}-\mathrm{I}}$ and $\mathrm{LpA}-\mathrm{I}_{\mathrm{A}-\mathrm{I}}$ in a deep-frozen reference pool of human plasma, which then served as a secondary calibrator for the differential turbidimetric assay:

a) LpA-I isolated by chromatofocusing was used as a standard in a 'tandem gel' electroimmunoassay for $\mathrm{LpA}-\mathrm{I}_{\mathrm{A}-\mathrm{I}}$. Apolipoprotein A-I had been measured in this preparation by zone immunoelectrophoresis $(16,17)$ in reference to a lyophilized commercial standard serum (Reference Standard for human apolipoproteins, Immuno AG, apolipoprotein A-I: $0.825 \mathrm{~g} / \mathrm{I})$.

b) LpA-I was measured in terms of its apolipoprotein A-I content in the supernate after precipitation of LpA with anti-apolipoprotein A-II. Here again a commercial reference serum (Apolipoprotein Standard Boehringer Mannheim, apolipoprotein A-I: $1.45 \mathrm{~g} / \mathrm{l}$ ) served as the standard.

\section{Miscellaneous analytical methods}

Zone immunoelectrophoresis $(16,17)$ and discontinuous polyacrylamide gel electrophoresis $(\mathrm{T}=12.5 \%, \mathrm{C}=2.7 \%)$ in the presence of SDS (18) were performed as described. Cholesterol, triacylglycerols and phospholipids were measured enzymatically using commercial reagents (Boehringer Mannheim). VLDLcholesterol and HDL-cholesterol were determined with a combined centrifugation/precipitation method (19). $\mathrm{HDL}_{2}$ and $\mathrm{HDL}_{3}$ were separated by ultracentrifugation at $d=1.125 \mathrm{~kg} / \mathrm{l}$ in the supernate after precipitation (phøsphotungstate/ $\mathrm{MgCl}_{2}$ ) of apolipoprotein B-containing lipoproteins (20). 


\section{Statistics}

The statistical analysis (rank sum test of Mann, Whitney, and Wilcoxon, Spearman's rank correlation) was carried out with the SPSS $^{x}$ batch system (release 2.0 on Sperry 1100 ).

\section{Results}

\section{Preparation of LpA-I}

A representative protein profile obtained by chromatofocusing of HDL is shown in figure 1a. Fractionation of the same sample in the presence of glycerol but under otherwise identical conditions apparently diminishes the heterogeneity of the elution pattern (fig. 1b). Since glycerol stabilizes proteins at their isoelectric point this possibly indicates that in the absence of glycerol artificial polymorphism may have been generated.

On SDS-PAGE and 'tandem gel' immunoelectrophoresis (fig. 2) the shaded fraction in the elution curve of figure $1 \mathrm{~b}$ contained apolipoprotein A-I but no apolipoprotein A-II. It was therefore considered to be a form of LpA-I and used to standardize the turbidimetric assay.
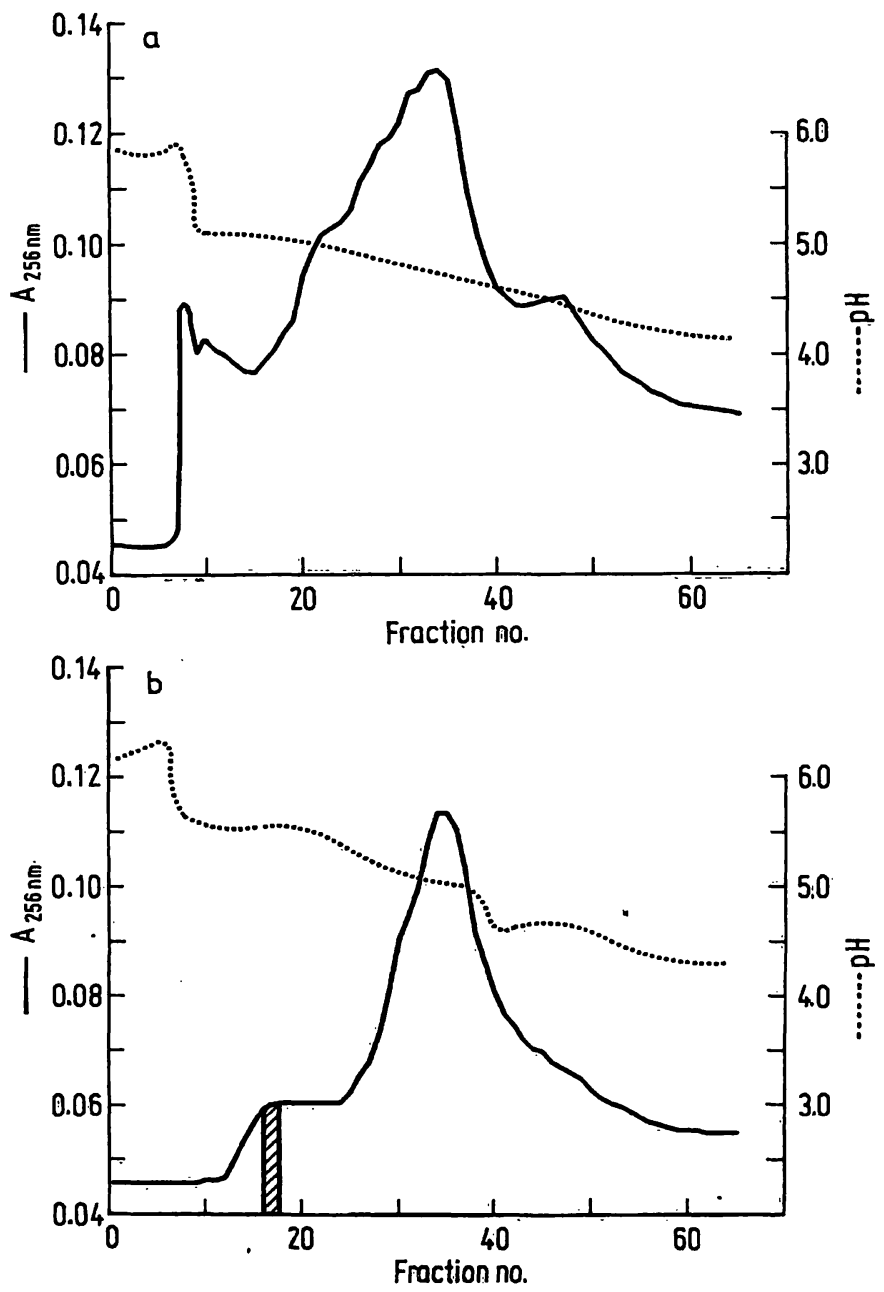

Fig. 1. Preparation of LpA-I by chromatofocusing (see text for experimental conditions) a) in the absence of glycerol b) in the presence glycerol at a final concentration of $250 \mathrm{ml} / \mathrm{l}$.

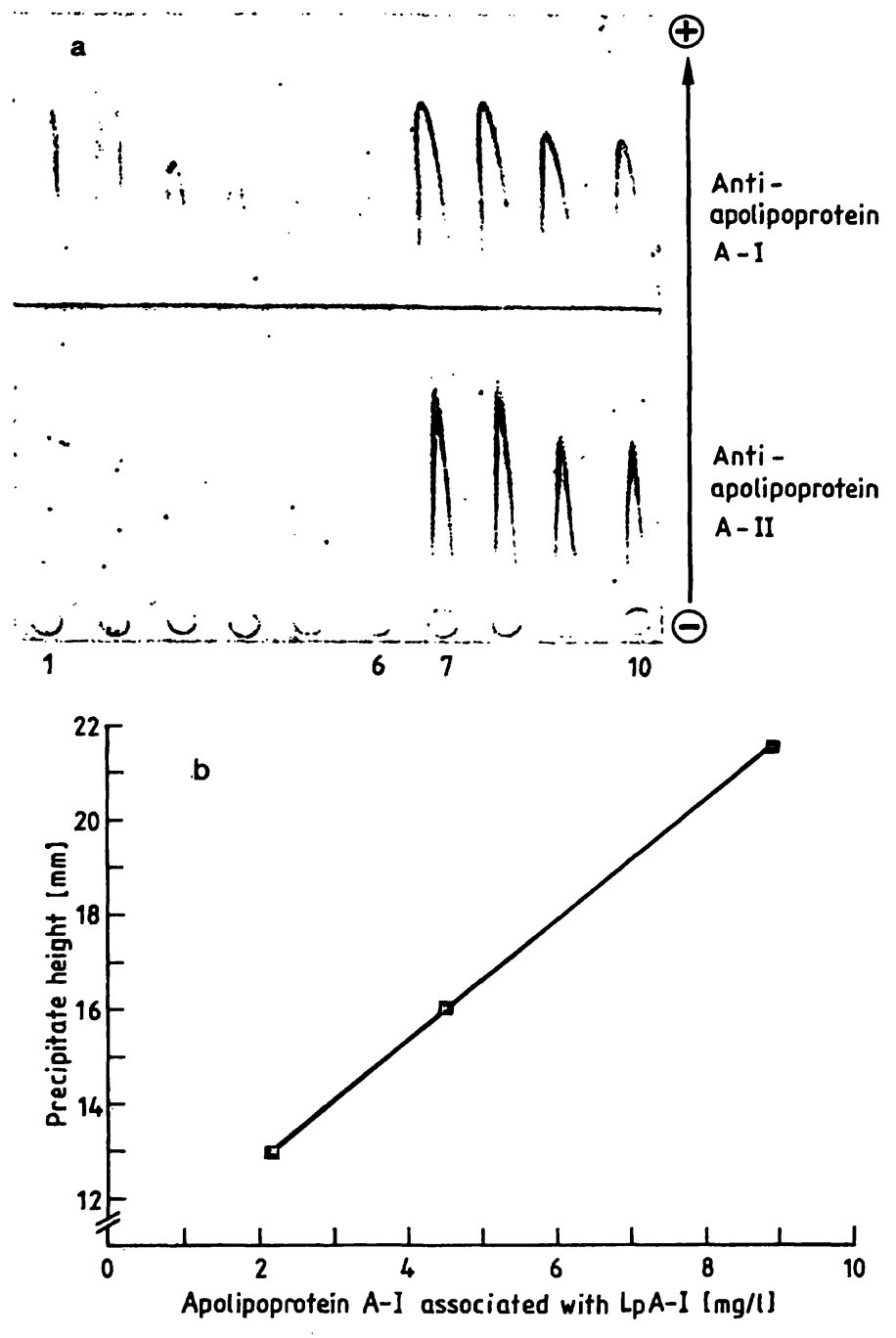

Fig. 2. a) Calibration of a secondary standard for the determination of $\mathrm{LpA}-\mathrm{I}_{\mathrm{A}-1}$ by 'tandem gel' electroimmunoassay. Anti-human-apolipoprotein A-II was added to the lower, anti-apolipoprotein A-I to the upper gel section. Wells $1-6$ contained three different amounts of purified LpA-I (in duplicate); $1: 50$ and $1: 80$ dilutions of the secondary standard were run in wells 7-10.

b) Standard curve. Each point represents the mean precipitate length of the respective LPA-I dilution (wells $1-6$ in a).

Differential immunoturbidimetric determination of $\mathrm{LpA}_{\mathrm{A}-\mathrm{I}}$ and $\mathrm{LpA- \textrm {I } _ { \mathrm { A } - \mathrm { I } }}$

On analysis in the 'tandem gel' electroimmunoassay the reference serum contained $0.590 \mathrm{~g} / 1$ apolipoprotein A-I associated with LpA-I. As quantified by zone immunoelectrophoresis its total apolipoprotein A-I concentration was $1.332 \mathrm{~g} / \mathrm{l}$. The turbidimetric assessments gave values of $0.599 \mathrm{~g} / \mathrm{LpA}-\mathrm{I}_{\mathrm{A}-\mathrm{I}}$ and $1.322 \mathrm{~g} / \mathrm{l}$ total apolipoprotein A-I. The two standardization procedures therefore closely agree with each other.

Supernates $(0.1 \mathrm{ml}$ aliquots) after the precipitation of LpA were checked for the presence of residual apolipoprotein A-II by means of zone immunoelectrophoresis and a sensitive ELISA (detects down to $2 \mathrm{ng}$ 
apolipoprotein A-II) without further dilution. Irrespective whether the initial precipitation of apolipoprotein A-II containing lipoproteins was conducted in 10-, 15-, 20-, 30-, or 40-fold dilutions of the samples, absorbance readings in the enzyme immunoassay did not significantly exceed blank values. Consistently, on zone immunoelectrophoresis, neither supernate contained apolipoprotein A-II (cf. fig. 3). This indicates that apolipoprotein A-II containing lipoproteins are virtually completely removed by the immunoprecipitation step throughout the concentration range covered by the turbidimetric assay.

Calibration curves for the estimation of $\mathrm{LpA}-\mathrm{I}_{\mathrm{A}-\mathrm{I}}$, total apolipoprotein A-I and apolipoprotein A-II constructed from dilutions of the reference serum are shown in figure 4 . Within a broad measuring range there are linear responses to the amounts of either antigen. The standard curves for apolipoprotein A-I in either LpA-I or whole plasma coincide, suggesting that the immunoreaction is insensitive to the nature of the apolipoprotein A-I containing particle.

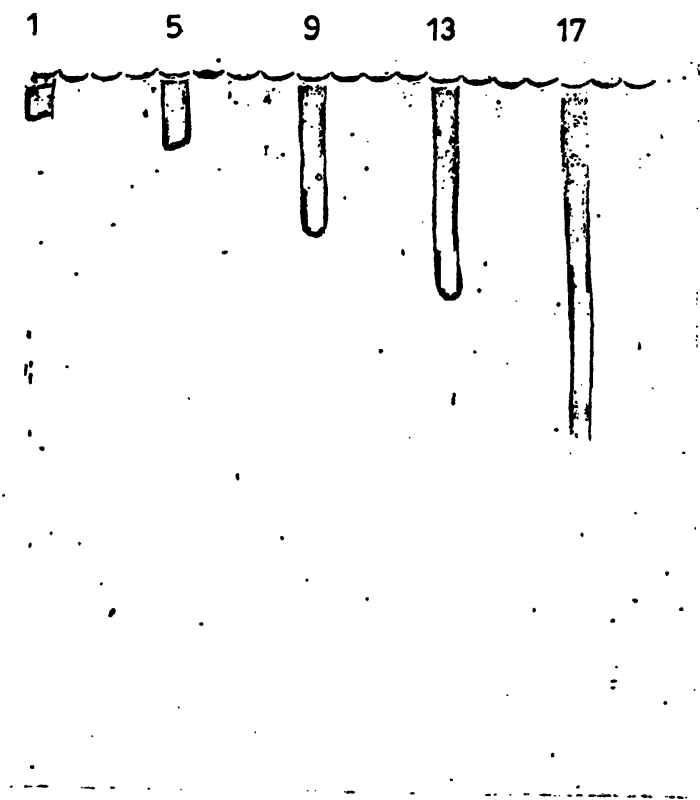

Fig. 3. Zone immunoelectrophoresis assay for apolipoprotein A-II in the supernate after immunoprecipitation of lipoproteins containing apolipoprotein A-II. The gel contained $8 \mathrm{ml} / \mathrm{l}$ anti-apolipoprotein A-II $\gamma$-globulin fraction (from sheep, Boehringer Mannheim). In correspondence with the standard curve of the differential turbidimetric assay, aliquots of a single plasma sample were diluted 10-, 15-, 20-, 30-, and 40-fold with 10 mmol/l potassium phosphate, $\mathrm{pH} 7.4,0.15 \mathrm{~mol} / 1 \mathrm{NaCl}$. These samples were then further diluted 20 -fold in order to account for the dilution introduced by the immunoprecipitation step and $20 \mu \mathrm{l}$ were loaded to rods 1,5 , 9,13 , and 17 . Rods $2,6,10,14$, and 18 contain $40 \mu$, rods $3,7,11,15$, and 19 contain $20 \mu$ l of the respective supernates after immunoprecipitation, and twofold dilutions of these supernates were applied to rods 4,8 , 12,15 , and 20 . After immunoprecipitation apolipoprotein A-II is absent from the supernates.

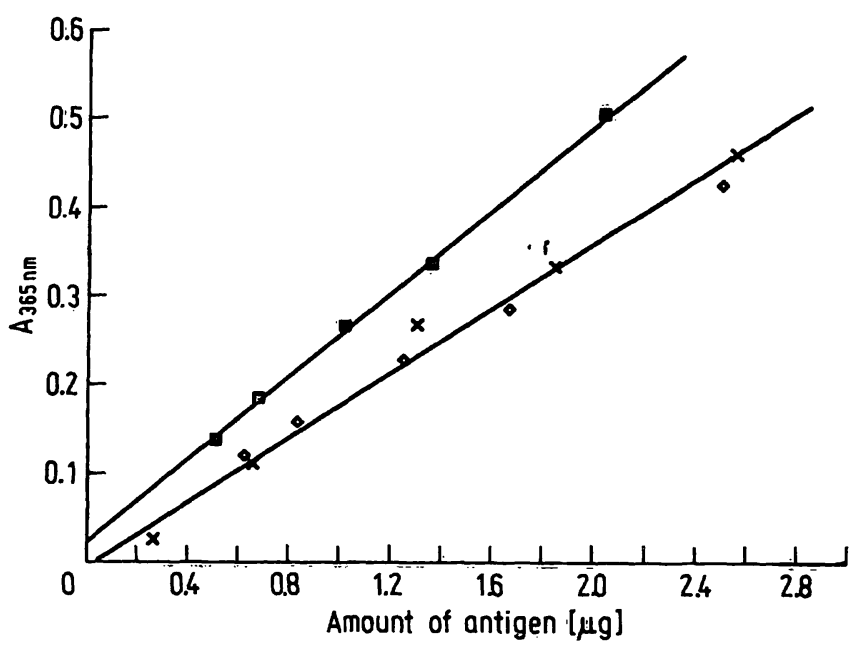

Fig. 4. Calibration curves for the turbidimetric determinations of apolipoprotein A-I (x), apolipoprotein A-II ( $\mathbf{a}$ ), and LpA-I $\mathrm{I}_{\mathrm{A}-\mathrm{I}}(\diamond)$. Each data point represents the mean of duplicate measurements (experimental details are described in the text).

In normolipidaemic samples, reagent blanks were always within 0.02 absorbance units. Some hypertriglyceridaemic sera, however, gave higher values, ranging from 0.03 to 0.06 . In order to exclude the possibility that net absorbance readings were substantially influenced by triacylglycerol-rich lipoproteins, we enriched a normolipidaemic plasma with highly concentrated VLDL prepared from a plasma pool of normolipidaemic donors. Within the range of $1.14 \mathrm{mmol} / 1$ to $3.2 \mathrm{mmol} / \mathrm{l}$ triacylglycerols absorbances remained unaffected although the sample blanks increased from 0.006 to 0.022 .

The within batch coefficient of variation was $4.4 \%$ $(n=10)$ for the determination of $\mathrm{LpA}_{\mathrm{A}-\mathrm{I}}$. Its between batch coefficient of variation was $8.6 \%$ as estimated by analyses of a deep frozen $\left(-25^{\circ} \mathrm{C}\right)$ plasma sample (mean LpA- $\mathrm{I}_{\mathrm{A}-\mathrm{I}}=0.62 \mathrm{~g} / \mathrm{l}$ ) on $\mathrm{n}=8$ working days.

\section{$\mathrm{LpA}_{\mathrm{A}-\mathrm{I}}$ and $\mathrm{LpA-I_{A-I }}$ in human plasma}

Along with lipoprotein and apolipoprotein concentrations, $\mathrm{LpA}_{\mathrm{A}-\mathrm{I}}$ and $\mathrm{LpA}-\mathrm{I}_{\mathrm{A}-\mathrm{I}}$ were determined in $\mathrm{n}=28$ ( 15 male and 13 female) healthy volunteers (age $26 \pm 6$ years). Results are compiled in table 1 . Apolipoprotein A-II and $\mathrm{LpA}_{\mathrm{A}-\mathrm{I}}$ concentrations did not differ significantly between the sexes, but total apolipoprotein A-I was significantly higher in males than in females, and the difference evidently originated in changes of LpA-I rather than of LpA.

Correlations between LpA-I $\mathrm{I}_{-\mathrm{I}}, \mathrm{LpA}_{\mathrm{A}-\mathrm{I}}$, apolipoprotein and lipoprotein concentrations are compiled in table 2. As would be anticipated, there were good 
Tab. 1. Mean values (medians in parenthesis) for apolipoprotein A-I, apolipoprotein A-II, $\mathrm{LpA}_{\mathrm{A}-\mathrm{I}}$ and $\mathrm{LpA}_{\mathrm{A}-\mathrm{I}}(\mathrm{g} / \mathrm{l})$ in healthy subjects.

\begin{tabular}{llrr}
\hline & $\begin{array}{l}\text { Males } \\
(\mathrm{n}=15)\end{array}$ & $\begin{array}{l}\text { Females } \\
(\mathrm{n}=13)\end{array}$ & $\begin{array}{l}\text { Overall } \\
(\mathrm{n}=27)\end{array}$ \\
\hline $\begin{array}{l}\text { Apolipoprotein } \\
\text { A-I }\end{array}$ & $1.58 \pm 0.21$ & $* 1.88 \pm 0.35$ & $1.72 \pm 0.32$ \\
$(1.52)$ & $(1.82)$ & $(1.68)$ \\
Apolipoprotein & $0.61 \pm 0.08$ & $0.58 \pm 0.18$ & $0.60 \pm 0.13$ \\
A-II & $(0.62)$ & $(0.54)$ & $(0.59)$ \\
LpA-I $_{\text {A-I }}$ & $0.75 \pm 0.10$ & $* * 1.00 \pm 0.29$ & $0.86 \pm 0.25$ \\
& $(0.76)$ & $(0.94)$ & $(0.80)$ \\
LpA $_{\text {A-I }}$ & $0.83 \pm 0.18$ & $0.88 \pm 0.18$ & $0.85 \pm 0.18$ \\
& $(0.89)$ & $(0.90)$ & $(0.90)$ \\
\hline
\end{tabular}

Differences between males and females: ${ }^{*} \mathrm{p}<0.05,{ }^{* *} \mathrm{p}<0.01$ (rank sum test of Mann, Whitney, and Wilcoxon)

Tab. 2. Correlations between $\mathrm{LpA}_{\mathrm{A}-\mathrm{I}-\mathrm{I}}, \mathrm{LpA}_{\mathrm{A}-\mathrm{l}}$, apolipoproteins and lipoproteins (Spearman's rank correlation coefficients) in $\mathrm{n}=27$ healthy males and females.

\begin{tabular}{|c|c|c|c|c|}
\hline & $\begin{array}{l}\text { Apolipo- } \\
\text { protein } \\
\text { A-I }\end{array}$ & $\begin{array}{l}\text { Apolipo- } \\
\text { protein } \\
\text { A-II }\end{array}$ & $\mathrm{LpA}-\mathrm{I}_{\mathrm{A}-\mathrm{I}}$ & $\mathrm{LpA}_{\mathrm{A}-\mathrm{I}}$ \\
\hline Cholesterol & 0.277 & $* * 0.458$ & 0.179 & 0.153 \\
\hline Triacylglycerols & 0.049 & 0.198 & -0.001 & 0.118 \\
\hline Phospholipids & $* * 0.549$ & $* 0.354$ & $* 0.373$ & $* 0.358$ \\
\hline VLDL-cholesterol & 0.037 & 0.248 & -0.050 & 0.175 \\
\hline LDL-cholesterol & -0.113 & 0.250 & -0.170 & -0.017 \\
\hline HDL-cholesterol & **0.732 & 0.186 & $* * 0.646$ & 0.363 \\
\hline $\mathrm{HDL}_{2}$-cholesterol & $* * 0.630$ & -0.097 & $* * 0.668$ & 0.267 \\
\hline $\mathrm{HDL}_{3}$-cholesterol & $* * 0.481$ & *0.435 & 0.216 & $* 0.417$ \\
\hline
\end{tabular}

${ }^{*} \mathrm{p}<0.05,{ }^{* *} \mathrm{p}<0.01$

correlations between apolipoprotein A-I and HDLcholesterol, $\mathrm{HDL}_{2}$-cholesterol, and $\mathrm{HDL}_{3}$-cholesterol. Apolipoprotein A-II, in contrast, was significantly associated only with $\mathrm{HDL}_{3}$-cholesterol, and not with $\mathrm{HDL}$-cholesterol or $\mathrm{HDL}_{2}$-cholesterol. Intriguingly, LpA-I was more closely correlated with $\mathrm{HDL}_{2}$ than with $\mathrm{HDL}_{3}$, and $\mathrm{LpA}_{\mathrm{A}_{-I} \mathrm{I}}$ was more strongly correlated with $\mathrm{HDL}_{3}$ than with $\mathrm{HDL}_{2}$.

\section{Discussion}

The turbidimetric procedure for the differential determination of $\mathrm{LpA}-\mathrm{I}_{\mathrm{A}-\mathrm{I}}$ and $\mathrm{LpA}_{\mathrm{A}-\mathrm{I}}$ is rapid and simple. As has been verified by an ELISA technique and zone immunoelectrophoresis, the immunoprecipitation with anti-apolipoprotein A-II affords complete removal of apolipoprotein A-II containing particles. Thus the subsequent assay for $L p A-I_{A-I}$ is specific. Two strategies for its standardization arrived at vir- tually identical results. This suggests that the procedure has been calibrated accurately, and that, in routine practice, the turbidimetric determination of apolipoprotein A-I in the supernate after precipitation of LpA will permit convenient yet accurate standardization. Hence, the differential method is readily available to any laboratory already running turbidimetric determinations of apolipoprotein A-I and apolipoprotein A-II.

Although in general the incorporation of detergents into turbidimetric assays eliminates background turbidity, they were omitted here in order to preserve the original lipoprotein structure. A sample blank should therefore be run in parallel in particular for hypertriglyceridaemic sera.

Hitherto, differential quantitation of LpA and LpA-I have been carried out by 'tandem gel' (i. e. double gel) electroimmunoassay $(11,12)$, ELISA (13) or by radioimmunoassay after precipitation of LpA (14). This is the first report on a turbidimetric assay for the two particle species. Compared with the other techniques it has several advantages: it is less tedious, does not demand specific equipment and may partially be automated. Drawbacks are antibody consumption and comparatively lower sensitivity which, however, is perfectly adequate for determination of plasma concentrations encountered in practice, and the method incidentally avoids large-scale dilution as a source of analytical error.

Differential measurement of LpA and LpA-I allows the straightforward classification of variations in the plasma apolipoprotein A-I/A-II ratio which, in principle, may be brought about by either changes in the composition of the apolipoprotein A-containing lipoproteins or by variations in the relative proportions of their subspecies.

Our reference values for LpA-I and LpA were established in a limited population sample and may therefore be considered as preliminary. Nevertheless, they are in fair accordance with data obtained with 'tandem gel' electroimmunoassay (11) and differential antibody ELISA (13), and, in keeping with the latter study, they suggest that the well documented sex difference in apolipoprotein A-I is attributable to LpA-I rather than to LpA.

The present work also provided statistical evidence that LpA-I is associated to some extent with $\mathrm{HDL}_{2}$, which is concurrently regarded the major anti-atherogenic HDL-subfraction. This may be related to the observation that within $\mathrm{HDL}_{2}$ roughly two thirds of apolipoprotein A-I reside on the LpA-I subspecies (13). 
In conclusion, our method provides an efficient tool for the quantitative differentiation of LpA and LpA-I. Further clinical and experimental research is now required to gain insights into the physiological and diagnostic significance of the two particle subpopulations.

\section{References}

1. Hessel, L. W. \& Brakman, P. (1981) Epidemiology of highdensity lipoproteins. In: High Density Lipoproteins. (Day, C. E., ed.) Marcel Dekker Inc., New York, Basel, pp. 535558.

2. Patsch, J. R. \& Gotto jr., A. M. (1987) Metabolism of high density lipoproteins. In: New Comprehensive Biochemistry. (Neuberger, A. \& van Deenen, L. L. M., eds.) Vol. 14. Plasma Lipoproteins. (Gotto jr., A. M., ed.) Elsevier, Amsterdam, pp. $221-259$.

3. Jonas A. (1987) Lecithin cholesterol acyltransferase. In: o.c. (2), pp. $299-333$.

4. Gianturco, S. H., Bradley, W. A. Lipoprotein receptors. In: o.c. (2), pp. $183-220$.

5. Jahn, C. E., Osborne, jr., J. C., Schaefer, E. J. \& Brewer, jr., H. B. (1983) Eur. J. Biochem. 131, 25-29.

6. Albers, J. J. \& Aladjem, F. (1971) Biochemistry 10, 34363442.

7. Borut, T. C. \& Aladjem, F. (1971) Immunochemistry 8 , $851-863$.

8. Norfeldt, P.-I. P., Olofsson, S.-V., Fager, G. \& Bondjers, G. (1981) Eur. J. Biochem. 118, 1-8.

9. Cheung, M. C. (1986) Characterization of apolipoprotein A containing lipoproteins. In: Methods Enzymol. (Colowick, S. P. \& Caplan, N. O., eds.) Vol. 129. Plasma Lipoproteins. Part B. Characterization, Cell Biology \& Metabolism. (Albers, J. J. \& Segrest, J. P., eds.) Academic Press, New York, pp. $130-145$.

\section{Acknowledgements}

The authors thank Mrs. Sabine Cezanne and Mrs. Christine von Hayn for their excellent technical assistance. This study was supported by grants from the Scheidel-Stiftung and the RieseStiftung, Frankfurt am Main.

$$
i
$$

10. Barbaras, R., Puchois, P., Fruchart, J.-C. \& Ailhaud, G. (1987) Biochem. Biophys. Res. Commun. 142, 63-69.

11. Atmeh, R. F., Shepherd, J. \& Packard, C. J. (1983) Biochim. Biophys. Acta 751, 175-188.

12. März, W., Hintze, J. \& Groß, W. (1987) $18^{\text {th }}$ FEBS Meeting, Ljubljana, p. 227 (Abstract).

13. Koren, E., Puchois, P., Alaupovic, P., Fesmire, J., Kandoussi, A. \& Fruchart, J.=C. (1987) Clin. Chem. 33, 38-43.

14. Cheung, M. C. \& Albers, J. J. (1982) J. Lipid Res. 23, $747-753$.

15. Nestruck, A. C., Niedmann, P. D., Wieland, H. \& Seidel, D. (1983) Biochim. Biophys. Acta 753, 65-73.

16. Vesterberg, O. (1980) Hoppe Seyler's Z. Physiol. Chem. $361,617=624$.

17. Groß, W. \& März, W. (1986) Ärztl. Lab. 32, 143-153.

18. Hames, B. D. \& Rickwood, D. (1981) Gel Electrophoresis of Proteins: A Practical Approach. IRL Press Ltd., Oxford and Washington.

19. März, W. \& Groß, W. (1986) Clin. Chim. Acta 160,1-18.

20. März, W. \& Groß, W. (1988) Ärztl. Lab. 34, in press.

Prof. Dr. W. Groß

Gustav Embden-Zentrum

der biologischen Chemie

Klinikum der J. W. Goethe-Universität

Theodor Stern-Kai 7

D-6000 Frankfurt am Main 70 